\title{
Hay-meadows production and weed dynamics as influenced by management
}

\author{
DANIELE MAGDA, JEAN-PIERRE THEAU, MICHEL DURU, AND FRANÇOIS COLENO
}

Authors are researchers, Institut National de la Recherche Agronomique, Département Systèmes Agraires et le Développement, Unité d'Agronomie, B.P. 27, 31326 Castanet-tolosan, France.

\begin{abstract}
Managers of extensive livestock systems generally have 2 goals for permanent grassland management: to obtain sufficient dry matter to feed animals and to avoid the establishment and dominance of unpalatable species. Hay production in French Pyrenean meadows is dependant on the need to balance grazing and cutting dates to produce maximum biomass for hay stock and to prevent seed recruitment of Chaerophyllum aureum L., one of the major invasive unpalatable species. Experiments and observations on a set of meadows within farms show that optimal dates calculated from degree-days for cutting or spring grazing of $C$. aureum fitted to seed production and apex development respectively, decreases hay yield. This decrease is related to the earliness of the cut in regard to sward growth or to the biomass loss by senescence due to the vegetative regrowth of the sward after spring grazing. Compromises and choices have to be made for each meadow by the farmer according to its potential production, the risk of invasion by $C$. aureum, and its role in the forage system.
\end{abstract}

Key Words: management sequences, permanent grasslands, herbage growth, weed population demography

In European livestock systems in mountain areas, grazed meadows often represent around $80 \%$ of the permanent grassland area at the farm level. The remaining $20 \%$ is grass used exclusively to yield hay or silage for animal wintering.

A critical point of this management system is to ensure, each year, sufficient dry matter yield of hay or silage to feed animals during the entire winter period (Theau et al. 1998). Any shortfall in stored feed requires hay purchases which threaten the economic sustainability of such systems. Topography and socio-economic trends favor valley bottom meadows, which are used both for grazing and hay production. Relatively recent changes in production organisation and in grassland management schedules (chronological order of farming operations and characteristics of the operations), have reinforced competition between grazing and cutting. Moreover, populations of undesirable species in permanent grasslands have markedly increased during the last few decades as a result of less intensive management practices in farming systems, leading to a reduction of grazing or cutting intensity (de Hullu et al. 1985, Bobbink and Willems 1993). Due to the unpalatable nature of these species, desirable forage

Manuscript accepted 11 Jul. 02.
Resumen

Los manejadores de sistemas extensivos de ganado generalmente tienen dos metas para el manejo de zacatales perennes: Obtener suficiente materia seca para alimentar a los animales y evitar el establecimiento y dominancia de especies no gustadas por el ganado. La producción de heno en praderas "French Pyrenean" depende de la necesidad de balancear las fechas de apacentamiento y corte para producir la máxima biomasa de heno para almacenar y prevenir la acumulación de semilla de Chaerophyllum aureum L., una de las principales especies invasoras sin gustocidad. Experimentos y observaciones hechas en un grupo de praderas dentro de granjas muestran que las fechas optimas calculadas a partir de grados-día para corte o apacentamiento en primavera del $C$. aureum se ajustaron a la producción de semilla y desarrollo del ápice respectivamente y disminuyen el rendimiento de heno. Esta disminución es relacionada a lo temprano del corte con respecto al crecimiento de la pradera o a la perdida de biomasa por senescencia debida al rebrote vegetativo de la pradera después del apacentamiento en primavera. Arreglos y elecciones tienen que ser hechos por el granjero para cada pradera de acuerdo a su potencial de producción, el riesgo de invasión de $C$. aureum y su papel en el sistema forrajero.

species are often driven out by competition. For these reasons, total dry matter production and the proportion eaten by animals is reduced significantly.

Generally, the impact of management practices on biomass production and species population dynamics have been studied separately and very often only with regard to a simple technical operation (fertilization or grazing and cutting regimes). The purpose of this study was to define efficient grassland management systems that maximize dry matter yield and limit the population densities of undesirable species. Weed population control involves finding a better match between management patterns and sensitive phenological stages of the target species to maintain a constant or decreasing population growth rate. In this study, we used observations, surveys and experiments on a set of permanent meadows belonging to French Pyrenean livestock owners to assess the effect of cutting date, presence and date of spring grazing and manuring on dry matter yield at haymaking time and on the population density of Chaerophyllum aureum L. representing a major invasive perennial weed of meadows. We focused on the impact of these technical operations on recruitment of $C$. aureum seed as the most sensitive stage in the life cycle of this species (Magda and Jarry 2000). 


\section{Materials and Methods}

\section{Study site: recording of manage- ment operations}

Surveys of management regimes, herbage production and $C$. aureum population density were carried out on 52 meadows belonging to 4 farms in the Ercé valley in the Central French Pyrenees $\left(0^{\circ}\right.$ $\left.30^{\prime} \mathrm{E}, 42^{\circ} 48^{\prime} \mathrm{N}\right)$. These permanent meadows are natural grassland communities with high species diversity. About 19 different species represent $90 \%$ of the grazed meadow biomass: about $60 \%$ of them are grasses (data not published).

These 19 or so species, along with higher altitude communally owned pasture, form the basis of traditional Pyrenean meat production systems. Each meadow management regime was identified from direct observations and surveys of farmers. The different technical operations (e.g., cutting, grazing, manuring, etc.) and their timing were recorded. Grazing takes place in spring and fall, before and after haymaking. Sward mean height after spring grazing was estimated from 50 sward stick measurements along a transect within each meadow (Duru and Ducrocq 1998). This height assesses the grazing intensity.

\section{C. aureum life cycle, apex develop- ment and seed viability}

Chaerophyllum aureum is one of about 300 species present naturally in permanent grasslands between 500 and $1,800 \mathrm{~m}$ in Europe (Gonnet 1989). Being very competitive, it is responsible for major infestations of hay meadows in less intensive livestock systems. Grazed only at a very early stage, it very soon becomes unpalatable to sheep and cows because of the concentration of lignified tissues in its shoots. It is a long-lived perennial (at least 7 years) that spreads solely by sexual reproduction, producing achenes which ripen from late July to late August and are distributed by dehiscence up to $20 \mathrm{~m}$ from the mother plant (Gonnet 1989). The seedbank is transient (Grime et al. 1988). Previous experimental studies on demography of $C$. aureum populations have elucidated its population dynamics strategy and identified sensitive stages in its life cycle in relation to management practices (Magda 1998, Magda and Jarry 2000). Restricting recruitment of new individuals is the only way to maintain or decrease population density by management of adult fecundity, seed dispersion and seedling survival.
The consequences of defoliation by grazing of the $C$. aureum adult apex on the development of reproductive structures were tested experimentally. The dynamics of apex development of $C$. aureum adults from spring regeneration were followed to determine the height of the apex within the sward at different times. Twenty-two plots $(2.50 \times 1.20 \mathrm{~m})$ were located in an ungrazed meadow colonized by $C$. aureum with 8 replicate plots at each of the 4 observation dates. Ten main stems per plot were sampled every 12 days between the beginning of spring regrowth (23 March, i.e. at 394 degree days) and the end of vegetative growth (4 May, 782 degree days). The height above ground and length of each stem apex were measured at each date. After each sampling date, the 8 plots were cut to record the effect of removing the main stem apex on the reproductive capacity of the individual. Plots were cut with a mower, leaving a residual herbage height of $5 \mathrm{~cm}$. This height was measured with a sward stick in most of the meadows after grazing.

Germination tests were done on $C$. aureum seeds after a period in manure to see whether manuring might affect longdistance seed dispersion for this species. Four cotton bags, each containing 100 seeds harvested from $C$. aureum populations established in the study site, were placed in January in 2 different manure heaps made the month before. Bags were placed at 2 different depths within each heap at 10 and $40 \mathrm{~cm}$ under the surface. Temperatures were recorded regularly with a Campbell thermocouple probe. Seeds were excavated the following spring (after 4 months) or a year later (after 16 months) to represent the times generally observed from farmers' practices between manure collection and its spreading. Seeds were buried in boxes filled with soil taken from the study site but from meadows not colonised by Chaerophyllum aureum and placed directly in the environmental conditions of the site. Seed germination rate was calculated from seedling surveys made in spring, which is the only time of year this species germinates. This rate was compared with that of control seeds which had never been stocked in manure but harvested at the same time and from the same populations.

\section{Chaerophyllum aureum abundance surveys}

Chaerophyllum aureum abundance was recorded within each meadow at 2 different dates in spring and summer on $4 \mathrm{x}$ $0.25 \mathrm{~m}^{2}$ plots. These 2 sampling dates were chosen to avoid underestimating populations as a result of missing juveniles in spring or intensively grazed adults.

Chosen at random over the whole meadow, the sample of 8 different plots allows the population to be estimated at the field level, taking into account thef spatial variation in density. Abundance was visually assessed for each plot, noting 1 if $C$. aureum was present, otherwise 0 . Total scores for the whole meadow could thus vary from 0 to 8 .

Correlations between management regime and abundance of $C$. aureum plants were analyzed by a non-parametric test adapted for small and independant samples, the so-called Wilcoxon-MannWhitney test (Scherrer 1984).

\section{Herbage Mass Measurement}

Each meadow's production was estimated by measurement of standing herbage mass from the same plots which were used to assess $C$. aureum abundance and taking into account the spatial variation of the sward over the whole meadow area. These measurements were made before spring grazing (20 April-19 May 1998) and summer cutting (4 June-13 July 1998) for the grazed meadows. For the ungrazed meadows, a first measurement of herbage mass was also made at the time of spring grazing. Each sward plot was cut at $2 \mathrm{~cm}$ above ground level with a small hand mower. Each plot biomass was weighed after drying at $80^{\circ} \mathrm{C}$ for 48 hours.

\section{Nutrient indices determination}

The herbage sampled for mass measurement was milled through a $0.8 \mathrm{~mm}$ screen and analyzed for nitrogen (Kjeldhal 1883), phosphorus (Murphy and Riley 1962) and potassium. To assess nitrogen status, we used the "dilution curve" method (Lemaire and Salette 1984). During herbage regrowth (after cutting or grazing), nitrogen concentration $(\mathrm{N})$ decreases as the aboveground herbage mass (HM) increases according to the relation: $\mathrm{N} \%=\alpha * \mathrm{HM}^{-\beta}$, nitrogen being the nitrogen concentration in g per $100 \mathrm{~g}$ of biomass, herbage mass the above-ground herbage mass in tonnes of dry matter $\mathrm{ha}^{-1}$, $\alpha$ the nitrogen concentration when herbage mass $=1 \mathrm{t} \mathrm{ha}^{-1}, \beta$ the coefficient of nitrogen dilution. With optimum nitrogen nutrition, the $\alpha$ and $\beta$ parameters are constant for all species, even legumes: $\alpha=4.8$ and $\beta=0.32$ (Duru et al. 1997, Lemaire and Gastal 1997). We used the parameters of this control curve to calculate a nitrogen index $(\mathrm{Ni})$ - the ratio between the measured nitrogen concentration of the above-ground herbage mass 
(HM) and the optimum nitrogen concentration as previously defined (Lemaire and Gastal 1997):

$$
\mathrm{Ni}=100 \times \mathrm{N} / 4.8 \mathrm{HM}^{-0.32}
$$

Critical herbage phosphorus and potassium concentrations were established, in relation with nitrogen concentration, and indices $\mathrm{Pi}$ (Phosphorus) and $\mathrm{Ki}$ (Potassium)were defined as the ratio between the actual phosphorus and potassium concentration and the optimal ones (Duru and Théllier 1997):

$$
\begin{aligned}
& \mathrm{Pi}=100 \times \mathrm{P} \% /(0.15+0.065(\mathrm{~N} \%)) \\
& \mathrm{Ki}=100 \times \mathrm{K} \% /(1.6+0.525(\mathrm{~N} \%))
\end{aligned}
$$

The indices could vary from 30 for very deficient herbage to 100 when the availability of nutrients allowed maximal growth.

\section{Time scale definition}

Two difficulties occur when comparing meadows for herbage mass production. First, meadows ranged from 600 to 1,000 $m$ in altitude; secondly, biomass measurements were not made on all plots on the same date. For this reason, time is expressed in degree days (degree days) i.e. the accumulated daily mean temperatures from 1 February or from the previous defoliation. This date corresponds to a change in the response of leaf extension to temperature as a consequence of the transition from vegetative to reproductive development (Parsons and Robson 1980). A correction $\left(-0.6^{\circ} \mathrm{C}\right.$ per $\left.100 \mathrm{~m}\right)$ was made to take into account the effect of altitude on temperature and so on growth processes.

\section{Results}

\section{Management schedules}

Spring grazing occurred on 32 of the 52 plots between about 500 and 1100 degree days after 1 February (Fig 1c), and the residual sward height varied from 3 to 18 $\mathrm{cm}$ (Fig 1d). Manure was spread on $40 \%$ of spring grazed meadows and on $82 \%$ of ungrazed meadows. The hay was cut after about 1500 degree days for ungrazed meadows and between 1200 and 1500 degree days for grazed meadows.

\section{Herbage nutrient status and stand- ing herbage mass}

Herbage Ni varied from 55 to 85 (Fig. 1a). This means that on average, the nutrient supply from fertilizers and soil allowed the plants to reach $70 \%$ of their growth potential (Lemaire and Gastal 1997). The nutrients phosphorus ( Fig. 1b) and potassium (not shown) indices were more variable, the lowest values being below 50 and the highest greater than 100 . They were significantly mutually correlated (Test Wilcoxon-Mann-Whitney, $\mathrm{P}<0.001)$. Standing herbage mass at the hay stage varied from 1500 to $8000 \mathrm{~kg} / \mathrm{ha}$ (Fig 1e).

At hay cutting time, the standing herbage mass (SHM) on ungrazed meadows averaged between 1000 and 1500 degree days (Fig 1e). It depended on the interaction between phosphorus and potassium nutrient status and time of harvest:

$$
\begin{aligned}
& \left(\mathrm{SHM}=-463+\sum_{F e b l}^{H T} \theta[0.035 \mathrm{Pi}+0.022 \mathrm{Ki}]\right. \\
& \left.\mathrm{n}=22, \mathrm{r}^{2}=0.42, \mathrm{se}=742, \mathrm{P}<0.001\right)
\end{aligned}
$$

There was no effect of nitrogen status on late hay yield but only one of phosphorus and potassium through stem growth (Duru and Calvière 1996). As there was a positive significant effect of accumulated temperature over the growth period, it means that for most of the plots, the maximum yield was not reached at the time where the herbage yield was measured, whereas the harvest period for 21 of the 22 plots occurred after 1100 degree days, which corresponds to the flowering period of most of the species (Calvière and Duru
1999). This result confirms experimental data for a range of nutrient supply treatments over 2 growing seasons (Calvière 1994) where it was observed that the dry matter accumulation increased up to 1500 degree days.

Following spring grazing, hay cutting time, averaged between 750 and 1000 degree days (Fig 1e). It was significantly lower $(\mathrm{P}<0.05)$ than that of ungrazed meadows (54\% on average) and positively correlated to the phosphorus status and the residual sward height (which reflects the intensity of spring grazing) and negatively correlated to spring grazing date:

$$
\begin{aligned}
& \mathrm{SHM}=1931+32.6 P i+132 R S H-\sum_{F e b l}^{G T} \theta(3.1) ; \\
& \left.\mathrm{n}=27, \mathrm{r}^{2}=0.74, \mathrm{se}=400\right) .
\end{aligned}
$$

This means that the later the grazing time $\left(\sum \theta\right)$ and the lower the residual sward height, the smaller was the standing herbage mass at the time of the hay cut. The difference in accumulated temperatures between spring grazing and hay yield times were not significant, meaning that the maximum yield was reached in the interval between the shortest (444 degree days) and the longest (956 degree days) regrowth times after grazing. This observation was in agreement with leaf lifespan for vegetative swards of cocksfoot (Dactylis glomerata L.) and tall fescue (Festuca arundinacea L.), the senescence
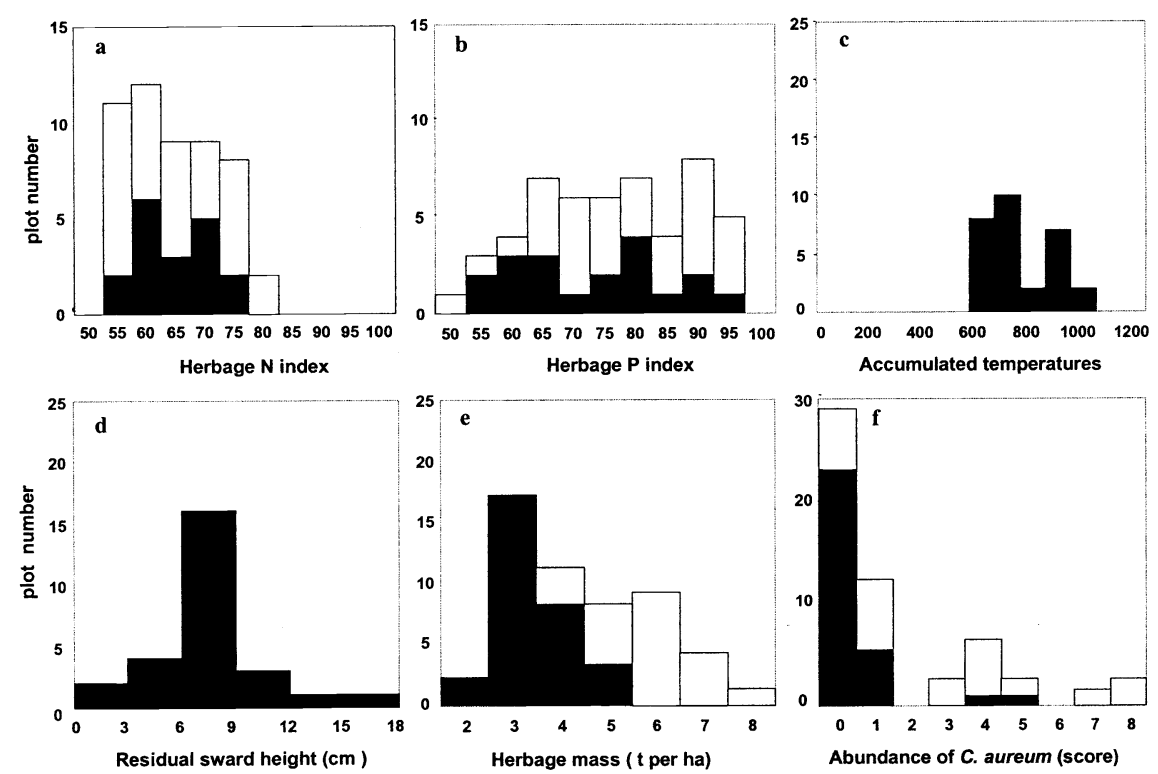

Fig. 1. Distribution of meadows (ungrazed in white; grazed in black) according to different variables. a) Herbage N Index, b) Herbage phosphorus index, c) Defoliation dates (degree days from 1 Feb. ), d) Residual sward height after defoliation (cm), e) Herbage mass $(\mathrm{kg} / \mathrm{ah}), \mathrm{f})$ Abundance classes of $C$. aureum. 
process beginning at about 800 degree days (Duru et al. 1993), and the maximum yield being reached between 800 and 1000 degree days.

For both forms of spring management, maximum yield occurred when senescence rate became equal to growth rate (Parsons 1988, Scarnecchia 1988). When there is no spring grazing, it is reached at a high standing herbage mass and a later date because of the presence of stem material. Indeed, over the stem elongation period, photosynthesis rate increased up to $65 \%$ (Woledge 1978) and was related to the height of the apex (Leafe 1978, Parsons 1988). This increase in photosynthesis rate acts as a sink (Varlet-Grancher et al. 1982), but the proportion of stem depends on nutrient status (Duru et al. 2000) and on grazing management (Briske 1996). Intense grazing in the spring removes the apex of grasses and forbs, causing the plants to remain vegetative. Senescence rate depends on leaf lifespan and phenology of the species. Leaf lifespan, which determines the beginning of senescence, is relatively constant for a given species when expressed in degree-days (Duru et al. 1993). For vegetative swards, the senescence process involved the whole leaf, whereas over the reproductive phase, the stem component of the sward did not senesce, at least to begin with.

Spring grazing management had the greatest effect on standing herbage mass at the hay stage, and on the pattern of herbage mass accumulation. The effect of herbage nutrient status was less significant. We expected that, due to apex removal, standing herbage mass with spring grazing would be about $50 \%$ lower and would increase only up to 1000 degree days after grazing time, while it increased at least up to 1500 degree days after the end of winter when there is no spring grazing.

\section{Impact of the technical operations schedule on $C$. aureum population density}

Chaerophyllum aureum was observed throughout the range of nitrogen index (Ni) measured within the whole sampled meadows. However, it was less abundant at nitrogen indices < 56 (Fig $1 \mathrm{a}, 1 \mathrm{f}$ ). Previous experimental studies have shown that a similar minimum fertility threshold (55 nitrogen index) is necessary for the establishment of $C$. aureum (Magda 1998). In this study site, the herbage nitrogen index varied from 55 to 85 , indicating that all areas are liable to be invaded by this species (Fig. 1a). There was a signifi-

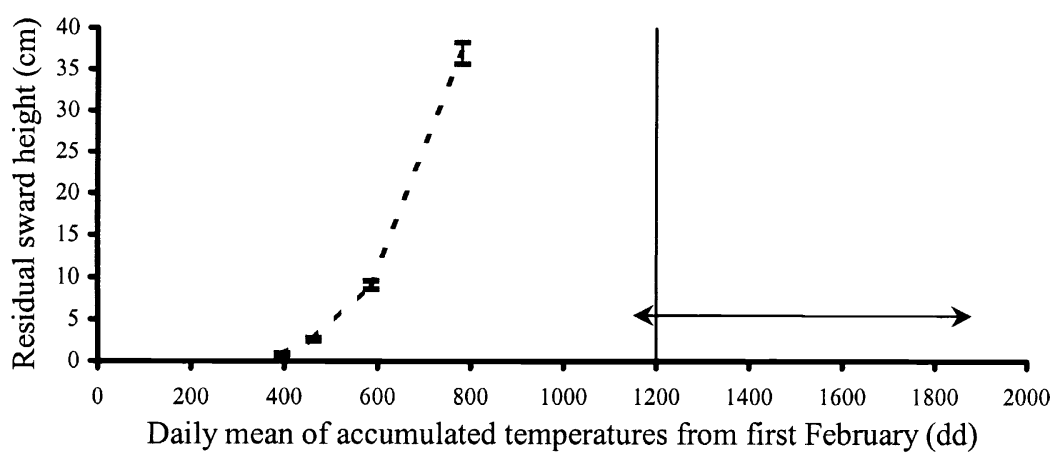

Fig. 2. C. aureum apex growth dynamics. Height of apex above ground $(\mathrm{Y}, \mathrm{cm})$ plotted against thermal time (X, Degree-Days) (dotted line) with a confidence interval calculated from a total of 280 measurements. The beginning of seed maturation period is represented by the vertical line. Horizontal line indicates the actual hay yield period.

cant and negative effect of grazing on $C$. aureum population density (Test Wilcoxon-Mann-Whitney, $\mathrm{z}=5.6, P=$ 0.05), (Fig. 1f). About $56 \%$ and $21 \%$ of whole fields sampled fell within the abundance classes 0 and 1 respectively. Seventy six percent of the sampled fields which were not colonized by $C$. aureum were grazed. The 2 highest abundance values of $C$. aureum (abundance classes 7 and 8 ) were found only in ungrazed fields.

These results clearly indicate the role of spring grazing in limiting $C$. aureum population density. Because adult resistance to defoliation has been already demonstrated (Magda 1998), these results confirm that grazing affects the recruitment process. It is likely that spring grazing first increases the seedling mortality rate due to trampling and biomass defoliation. We suspect that seedlings from emergence to the juvenile stage differ in sensitivity to biomass removal, but the most sensitive stage to grazing has not been determined. Secondly, spring grazing decreases the overall fecundity of the population by removing the shoot apex.

We show that apex removal during spring regrowth leads to purely vegetative stem development for $C$. aureum. To remove the main apex, date and height of defoliation through cutting or grazing has to be correlated (Fig. 2). This figure shows apex development schematically, so as to define the most efficient height for defolia-

Table 1. Percentage of germination on $C$. aureum seeds after a short or long period of storage in manure at 2 different depts, $10 \mathrm{~cm}$ and $40 \mathrm{~cm}$ under surface.

\begin{tabular}{lcccc}
\hline \hline Control & \multicolumn{2}{c}{$\begin{array}{c}\text { Short stocking } \\
\text { (4 months) }\end{array}$} & \multicolumn{2}{c}{$\begin{array}{c}\text { Long stocking } \\
(16 \text { (months) }\end{array}$} \\
& $-10 \mathrm{~cm}$ & $-40 \mathrm{~cm}$ & $-10 \mathrm{~cm}$ & $40 \mathrm{~cm}$ \\
\hline 69.6 & 72 & 0 & 61 & 0 \\
& 71 & 0 & 54 & 0 \\
\hline
\end{tabular}

tion according to date of grazing or cutting. For example, for a spring grazing date at 600 degree days, the maximum threshold of residual herbage height was $11.8 \mathrm{~cm}$. Moreover, at this date, $C$. aureum is not lignified and is entirely palatable for animals. Combining the data of Fig 1c, 1d and Fig 2, we deduce that for 24 of the 27 plots, the $C$. aureum apex must have been removed and that in most of the swards this species remained vegetative.

For the ungrazed fields, manure application was correlated significantly and positively to $C$. aureum population densities (Test Wilcoxon-Mann-Whitney, $\mathrm{z}=2.26$ $\mathrm{P}=0.05)$. This confirms the hypothesis that seed can be imported with manure. Experiments on seed viability after storage in manure show that $C$. aureum seeds are capable of germination even after several months storage in manure and with greater success for seeds distributed near the heap surface when it is not turned over (Table 1). These results confirm the potential role of manuring in dispersing $C$. aureum seeds and in increasing the risk of seed immigration into fertilised meadows.

The fact that the effect of manure supply was not significant for grazed fields supports the view that grazing is a major factor limiting seedling establishment and/or population fecundity.

The presence of $C$. aureum in $13 \%$ of grazed fields can be explained by the spatial heterogeneity of grazing, which main- 
tains favorable microsites and consequently allows seedlings to escape from disturbance and mortality. Some adults of $C$. aureum could be also leniently grazed, particularly with late grazing. This phenomenon, in addition to heavy seed shedding, can maintain populations at a relatively high density within grazed fields. It can also correspond to transitory changes of management, creating an opportunity for $C$. aureum seedlings to be established.

To define the timing of the sensitive period for efficient defoliation for seed production control, phenological surveys have been conducted within $C$. aureum populations already established in hay meadows. Results show that cutting for hay before 1200 degree days prevents the seed maturation process.

\section{Discussion}

From results on herbage yield and $C$. aureum population demography, it is possible to propose a grazing and cutting schedule to optimize fodder production on hay meadows colonized by $C$. aureum (Table 2). For ungrazed meadows, 1 cut before 1200 degree days would prevent $C$. aureum seed production. Also, sward biomass losses associated with the development of reproductive structures would be limited because of the earliness of the cut.

Spring grazing could limit recruitment of new $C$. aureum individuals through 2 processes: enhancement of seedling mortality (Magda and Jarry 2000) and prevention of development of reproductive structures through apex removal for $C$. aureum and also for 3 grasses associated with $C$. aureum (not shown). Grazing efficiency is dependent on its intensity as defined by the residual herbage height, which determines the probability that the apex escapes grazing. The lower the grazing intensity, the greater is the likelihood that $C$. aureum adults will not be grazed. Nevertheless, the efficiency with which grazing removes the $C$. aureum apex will be related to the ingestion behavior of animals, grazing intensity (number of animals per unit of land area) and number of days of grazing. Moreover, as time passes and $C$. aureum plants mature, diet selection by animals will increase the probability for apex to escape to defoliation. Therefore, a lower limit of grazing date at 600 degree days is recommended, with a residual herbage height of $11.8 \mathrm{~cm}$ (Fig. 2). This date corresponds to the lower limit of apex height. Before this date, grazing does not remove the apex of many species and especially $C$. aureum. Delaying grazing, as well as increasing the grazing intensity, increases the probability of removing the stem apex for many grass species (Gillet 1980).

If the farmer wants to minimize any risk of seed production, hay cutting should occur before 1200 degree days. But in this case, hay yield is considerably depressed. Cutting should be done not later than 1000 degree days during the regrowth period to avoid losses through senescence. Finally, a choice has to be made by farmers: whether to ensure maximum yield production and accept a risk of recruitment of new individuals or to accept a compromise for hay production and ensure long term $C$. aureum population control.

In the case of hay meadows not already colonized by $C$. aureum, we believe that the risk of invasion is largely dependent on manure spreading. If no manure is applied, the risk of immigration of $C$. aureum seeds is relatively low and management can be based on maximizing hay yield. This risk is also low if the nutrient index is sufficiently low to prevent any natural colonization.

Manuring greatly increases the probability of seeds reaching non-invaded meadows, particularly when the meadows are not close to other seed sources. In this latter case, farmers can adopt a prevention strategy and maintain spring grazing to control potential seedling populations or take the risk and alter the management schedule only when adults appear in the meadow.

The demographic strategy of $C$. aureum populations is clearly characterized by a great ability to reach high densities and to maintain these densities for a long time. Prevention of establishment therefore appears to be the best management strategy for this species.

\section{Conclusions}

This study shows that the schedule of management operations to control weed species can be proposed from a knowledge of the developmental dynamics of the species and the demographic strategy of its population. Differentiation of population dynamics traits among grassland weed species is possible and allows different appropriate control strategies to be proposed. We have shown that spring grazing and cutting for hay can efficiently control $C$. aureum infestation when they are applied, relatively constantly, at appropriate dates for the morphological and reproductive patterns of this species. However, C. aureum population dynamics are not independent of forage species dynamics within the grassland community. The sequence of management operations

Table 2. Sequences and timing of technical operations (cutting and grazing) for control of $C$. aureum and maximazation of hay yield (degree days, standing herbage mass).

\begin{tabular}{llll}
\hline \hline $\begin{array}{l}\text { Sequence of technical } \\
\text { operations }\end{array}$ & Limitation of $C$. aureum abundance & Maximization of hay yield \\
\hline Hay cutting & Grazing & $<1200$ degree days & $\begin{array}{l}<1500 \text { degree days, standing herbage mass }= \\
\text { f(herbage nutrient index) }\end{array}$ \\
\hline Grazing - Cutting & Cutting & $\begin{array}{l}\text { If grazing begins at }<600 \text { degree days, the regrowth } \\
\text { is reproductive } \rightarrow \text { hay yield up to } 1500 \text { degree days } \\
\text { should minimize herbage losses. } \\
\text { If grazing begins at }>600 \text { degree days, the regrowth is } \\
\text { vegetative } \rightarrow \text { yield time around } 1000 \text { degree days after } \\
\text { beginning of grazing (about } 1500 \text { degree days after 01/ } \\
\text { 02 if the swards were grazed at } 600 \text { degree days) should } \\
\text { minimize herbage losses. }\end{array}$ \\
& & \\
& & \\
& $<600$ degree days & $<1200$ degree days & \\
& $<600$ degree days & f(risk level accepted) & \\
& & \\
\hline
\end{tabular}


needed to control $C$. aureum depresses herbage yield and could adversely affect forage production. Spring grazing limits the establishment of new individuals of this species but also reduces hay yield to that of the regrowth biomass.

In a given year, estimation of herbage losses, with or without spring grazing, has to be made according to the size of the $C$. aureum population and the corresponding herbage mass (mainly $C$. aureum stems) which was rejected when animals were fed indoors. Without control, C. aureum will always become rapidly dominant, suppressing the remaining species in the community. In this case, biomass is productive only if $C$. aureum is maintained at a leafy stage, preventing lignified stem development and this is possible only if defoliation occurs early in spring before stem apex development.

The conflict between forage production and weed control can be resolved at farm level. Limiting $C$. aureum recruitment and improving hay yields call for the revision of grazing and cutting operations, selecting productive areas for hay, reserving invaded areas for grazing, and generally preventing any seed immigration. Silage production could allow earlier cutting, i.e. before weed seeds mature. Reducing $C$. aureum seed viability by stamping manure could be another way of reducing the risk of seed propagation, especially on meadows on which there is a lot of biomass production.

\section{Literature Cited}

Bobbink, R. and J.H. Willems. 1993. Restoration management of abandoned chalk grassland in the Netherlands. Biod. and Conserv. 2:616-626.

Briske, D.D. 1996. Strategies of plant survival in grazed systems: a functionnal interpretation. p. 37-68. In: Hodgson, J. and Illius (eds) The ecology and management of grazing systems. A.W.CAB International.

Calvière, I. 1994. Effets de la nutrition minérale et de la composition botanique sur la croissance de prairies permanentes au printemps : conséquences pour la prévision et le diagnostic de la biomasse récoltable et de sa qualité. Ph. D. Thesis, Univ. Toulouse III. Toulouse.

Calvière, I. and M. Duru. 1999. The effect of $\mathrm{N}$ and phosphorus fertilizer application and botanical composition on the leaf/stem ratio patterns in spring in pyrenean meadows. Grass and Forage Sci. 54:255-266.

de Hullu, E., T. Brouwer, and S.J. Ter Borg. 1985. Analysis of the demography of Rhinanthus angustifolius populations. Acta Botanica Neerlandica. 34:5-22.
Duru, M. and I. Calvière. 1996. Effets of phosphorus and $\mathrm{N}$ nutrition status and of botanical composition of permanent pastures on their growth in spring. Agronomie. 16:217-229.

Duru, M. and H. Ducrocq. 1998. La hauteur du couvert prairial : un moyen d'estimation de la quantité d'herbe disponible. Fourrages. 154:173-190.

Duru, M. and L. Thélier. 1997. N and P-K status of herbage : use for diagnosis of grasslands. In Diagnostic procedures for crop $\mathrm{N}$ management, Colloque de l'INRA. Poitiers.p.125-138. INRA.

Duru, M., G. Lemaire, and P. Cruz. 1997. The $\mathrm{N}$ requirements of grasslands, p. 59-72. In: G. Lemaire (ed.), Diagnosis of the $\mathrm{N}$ Status in Crops. Springer Verlag Press, Berlin.

Duru, M., V. Delprat, C. Fabre, and E. Feuillerac. 2000. Effect of nitrogen fertiliser supply and winter cutting on morphological composition and herbage digestibility of a Dactylis glomerata L. sward in spring. J. Sci. Food and Agr. 80:33-42.

Duru, M., E. Justes, A. Langlet, and V. Tirilly. 1993. Comparaison des dynamiques d'apparition et de mortalité des organes de fétuque élevée, dactyle et luzerne (feuilles, talles et tiges). Agronomie. 13:237-252.

Gillet, M. 1980. Les graminées fourragères. Gauthier-Villars (ed.).

Gonnet, J.F. 1989. Apport de la Biologie Micromoléculaire (flavonoides) à la compréhension de la structure et du fonctionnement de l'espèce allogame Centaurea montana (Composées) et de l'espèce autogame Chaerophyllum aureum (Ombellifères) au sein de deux groupements végétaux subalpins: prairie et megaphorbiaie. $\mathrm{PhD}$ Thesis, Univ. Claude Bernard. Lyon I.

Grime, J.P., J.G. Hodgson, and R. Hunt. 1988. Comparative plant ecology. Unwin Hyman, London.

Kjeldahl, J. 1883. Neue Methode zur Bestimmung des Stickstoffs in organischen Korpern. Z. Anal. Chem. 22:366-382.

Leafe, E.L. 1978. Physiological, environmental and management factors of importance to maximum yield of the grass crop, p. 37-79. In: ADAS/ARC (ed.), Maximising Yields of crops, ADAS/ARC Symposium. Harrogate, G.B.

Lemaire, G. and F. Gastal. 1997. N uptake and distribution in plant canopies, p.3-43. In: G. Lemaire (ed.), Diagnosis of the N Status in Crops. Springer Verlag Press, Berlin.

Lemaire, G. and J. Salette. 1984. Relation entre dynamique de croissance et dynamique de prélèvement d'azote pour un peuplement de graminées fourragères. I-Etude de l'effet du milieu. Agronomie. 4:423-430.

Magda, D. 1998. Effects of extensification on invasive populations of Chaerophyllum aureum in grasslands. J. Veg. Sci. 9 :409-416.

Magda, D. and M. Jarry 2000. Prediction of cutting effects on a population of Chaerophyllum aureum - a demographic approach. J. Veg. Sci. 11: 485-492.
Murphy, J. and J.B. Riley 1962. A modified single solution method for the determination of phosphate in natural waters. Analytica Chimica Acta. 27:31-36.

Parsons, A.J. 1988. The effect of season and management on the growth of grass swards, p.129-178. In: M. Jones, and M. B. Lazenby (ed.)., The Grass Crop. Chapman and Hall.

Parsons, A.J. and M.J. Robson. 1980. Seasonal changes in the physiology of S24 perennial ryegrass (Lolium perenne L.). 1. Response of leaf extension to temperature during the transition from vegetative to reproductive growth. Ann. Bot. 46: 435-444.

Scarnecchia, D.L. 1988. Grazing, stocking and production efficiencies in grazing research. J. Range. Manage. 41:279-281.

Scherrer, B. 1984. Biostatistique. Gaëtan Morin (ed).

Theau, J.P., F.C. Coleno, M. Duru, and Y. Rauzy. 1998. L'utilisation de l'herbe pâturée et fauchées en référence au potentiel de production des prairies. Fourrages. 156:589-601.

Varlet-Grancher, C., R. Bonhomme, M. Chartier, and L. Artis 1982. Efficience de la conversion de l'énergie solaire par un couvert végétal. Acta Oecol. Plant. $3: 3-26$.

Woledge, J. 1978. The effect of shading during vegetative and reproductive growth on the photosynthetic capacity of leaves in a grass sward. Ann. Bot. 42:1085-1089. 